\title{
THE ROLE OF NATIONALITY IN THE GENESIS OF MODERN TURKEY
}

\author{
MODERN TÜRKIYYE’NIN DOĞUŞUNDA MILLIYETÇILİĞİN ROLÜ
}

\author{
Erdal AYDIN ${ }^{1}$
}

\begin{abstract}
The relationship of modernization and nationality will be investigated in this article by reference of Turkish political history in the context of approaches of civil, ethnical and modernist nationalism. Modernization beginning with Ottoman State has been continued during Republic era. Nationality appearing especially after French Revolution in the west symbolizes emergence of national states as well as competition of common people in respect of rights and freedoms. Turkism, as well as Ottomanism and Islamism has been very strong in the late Ottoman State. Nationality was crucial element during National Independent Struggle and foundation of the Republic. Development and role of nationality from Ottoman to Republic has been analyzed in this essay in regard of modernization.
\end{abstract}

Keywords: Modernization, Nationality, Identity, National State.

Öz

Bu araştırmada Türk siyasi tarihi bağlamında modernleşme ve milliyetçilik olgusu arasındaki ilişki sivil, etnik ve modernist milliyetçilik yaklaşımları bağlamında ele alınmaktadır. Osmanlı ile başlayan modernleşme hikayemiz Cumhuriyet ile devam etmiştir. Milliyetçilik Batı'da bilhassa Fransız İhtilaliyle birlikte ulus devlet anlayışının ortaya çıkmasını ve toplumun büyük kısmını oluşturan avam tabakasının siyasal anlamda hak ve hürriyet mücadelesini sembolize etmektedir. Osmanlı'nın sön döneminde İslamcılık ve Osmanlıcılıkla birlikte Türkçülük çok belirgin bir şekilde varlığını hissettirmiştir. İstiklal Mücadelesinde ve Cumhuriyetin kuruluşunda milliyetçilik çok önemli bir saik olmuştur. Bu makalede Osmanlı döneminden Cumhuriyete milliyetçilik olgusunun gelişimi ve rolü modernleşme bağlamında analiz edilmiştir.

Anahtar Kelimeler: Modernleşme, Milliyetçilik, Kimlik, Ulus Devlet.

\footnotetext{
${ }^{1}$ Marmara Üniversitesi, erdal.aydin@marmara.edu.tr, Orcid: 0000-0003-1054-7782 


\section{Modernization and Nationality}

The concept of nation was transformed from a ordinary crowded community to founder of a sovereign state with French revolution and American revolution (Hobsbawm, 1995, p.14-45). Trends and tendencies of renewing, changes, transformations and progressives are bases of theories of modernizations. The concept of modernization may be explained as catching, keeping, governing, renewing and transforming time and space in sense of political, social, economic, military and technological standards.

According to Eisenstadt the modernization is a process of the spread of transformations in fields of social, economic and political systems emerging and developing in the western Europe and North America between $17^{\text {th }}$ and $19^{\text {th }}$ centuries to other European countries as well as fallowed by South American, Asian and African continents in the $19^{\text {th }}$ and $20^{\text {th }}$ centuries (Eisenstadt, 1966, p.1). It can be clearly seen that Western Europe and North America are fundamental actors of this process. The rest of the world countries fallow the wind and waves of this transformation in different stages.

The concept of modernization especially is preferred as an ideological tool by developed countries as well as intellectuals who impose developed countries as ideal models to their society. It is a handicap and tragically comics to blame values of your countries for favor of the other nations and cultures in regards of ideological approaches. For Emre Kongar, the concept of modernization has been formulated on the assumptions and mentality that all the other nations would fallow the same footsteps of the western societies (Kongar, 1981, p.217). In fact, this perspective is nothing than a result of western ethnocentrism and hegemony. That is why currently most of western intellectuals claim that conventional and feudal societies would pass and come to be modernize due to of the perspective of a progressive assumption.

Nationality is one of the fundamental pillars and fruits of the modernization defined as imagined community by Benedict Anderson (1991, p.1-7). It may be said that nationality is a core, essence and part of modernization. That is why nationality is a crucial instrument for countries that would like to be modernize. Nationality also is very functional element and a kind of strong spirit for most of countries while challenging and releasing from colonialism. This spirit of unification of community against colonial powers is also used to complete modernization in sense of copying and imitating the west by some of the developing countries which gaining their national and political dominance and independency.

Two important typologies of nationality appeared in the process of modernization in the west. The first and classical one is French nationalism while latter is German. Both of countries are permanently competitive powers in the history of Europe in sense of civilization, literature, art as well as state actors. The most fundamental character of French nationalism is a kind of civilization based on the cosmopolitanism, universality and Enlightenment. The French nation-state has come to the fore with French nationalism.

As a result of the simultaneous development of the French nationalism and the nationstate model in 1789 after the French Revolution, this model continued to be a good and powerful model for European countries as well as other countries in the long-term. As mentioned by Ayşe Kadıoğlu the problem of state searching the nation or nation looking for the state has not occurred in those western countries resembling French models (1998, s.211). Nationalism generally has evolved in a manner compatible with the nation-state and has become an attractive model in the European continent.

Comparing French nationalism power of German nationalism is based on the Romantism. Indeed, Romantism is a critique and alternative of Enlightenment. Since German 
nationalism has been appeared a half century ago before national state, ethnical and cultural elements were more dominant for its genesis. German nationalism has been shaped by the center of ethnical and cultural elements during the process of concluding the national state.

Thus, the state comes first before individuals in this system. In addition, language is the basic identity of the nation. For German philosopher Herder, language make human as human for description and measurement of humanity. Common language is the first step to construct a nation in this experience and approach. It is nothing than the reflection of the national spirit. Moreover, common language was fundamental precaution for a state and nation (Özkırımlı, 2009, p.38).

\section{The Seed of Kemalist Nationality}

The significance of Turkism and Turkish identity increased with the effect of modernization in the late Ottoman period before genesis of Kemalist nationality. During late of Ottoman State, along with the migration, Turkism and ideas of the homeland gained more importance day by day. From the end of the ninth century, the state began to lose huge lands in the Caucasus, Crimea, Crete and the Balkans. Indeed, the dissolution of the Balkan began after the siege of Vienna by Ottoman. After that it also provoked and accelerated nationalism among Balkanian ethnical communities as a result of increases of Western attack and spread toward Ottoman land as a crucial milestone (Karpat, 2012, p.30-57).

Because of this fact, Muslims living so called lands and the Turks came to Anatolia. As a result of these migrations, Turkism and ideas of homeland began to be more popular subject in the political system. Namik Kemal, for example, wrote the famous book of 'Vatan Yahut Silistre' (2011). Later it would have been a ground giving results of the national state in the era of Republic due to of using concepts like freedom, homeland in the field of literature and poetry (Göçek, 2002, s.64).

Yusuf Akçura elaborated and compared Ottomanism, Turkism and Islamism at the beginning of the twentieth century. In fact, these three political ideas were important during the period of II. Abdülhamit although Ottomanism began and encouraged by II Mahmud. It is known that Sultan Abdülhamit used these three ideologies for survival of the state. In the last period of the nineteenth century, significant developments took place in regards of the language due to the influence of nationalist movements. It's interesting that Yusuf Akçura advocated and estimated that Turkism would lead and defeat to other movements in the process of challenge and competition in 1904 (1976, p.19-36).

Statesmen like Ziya Pasha has pointed out the huge gap between common and palace languages. That is why they defended a pure and simple language in the public offices. There were advocates of simplifying the language of literature. Significant thinkers like Şemsettin Sami, Ahmet Mithat, Necip Asim accepted reasonable to call Ottoman instead of Turkish. In particular, Şemsettin Sami and Necip Asım encouraged the adoption and popularization of the Turkish language as a basis for the state and society, while advocating that foreign words such as Arabic and Persian should be avoided as much as possible (Kushner, 1977, s.58).

According to Ahmet Mithat, the Ottomans used the official language of the state in Turkish compared to the Seljuks and Ayyubis, but the non-Muslim subjects of the state had been attempted more to learn Turkish (Kushner, s.74). Majority of the Ottoman subjects could not speak, write and read Turkish. Because of the nation system in the Ottoman community, non-Muslim community leaders had to fallow official arrangements in favor of their communities. Therefore, a significant part of non-Muslims was deprived of Turkish.

Since these minorities could not know Turkish, they were not aware of the reform works in the political and social system. Turkish courses were introduced in the foreign 
schools to ensure that the minorities were more compatible within the political system and that the state could communicate with them. In 1913, the Union and Progressive Party government declared Turkish as the only language of instruction in the state high schools. Although the Union and Progressive Party did not directly express their Turkism, it would seem obviously most of them defended Turkism during the republic (Çağaptay, 1999, p.13).

Ismail Gasprinski, a Crimean Turkish writer, aimed to preserve the unity, identity and culture of the Turks in Russia with the weekly Tercüman newspaper published in Russia. Also Buharalı Süleyman Efendi who came from Central Asia published Lügat-1 Çağatay as well as Türkî-yi Osmaniyi. Moreover, Mehmet Sadık, a member of the tekke in Üsküdar published Üs-i Lisan-1 Türkiyi. In all these studies, it was supported that the native language of the Turks was Chagatai Turkish (Kushner, p.60).

The idea of Ottomanism became very important with the Tanzimat Edict in 1839. Although the loyalty and obedience of non-Muslims were desired by given minority rights but not appeared and arrived after declarations of reform. Therefore, nationalist movements in the Ottoman State did not stop after Tanzimat Edict too. The independence activities of nonMuslims have severely weakened the idea and identity of Ottomanism. Abdülhamit emphasized the importance of religion and Islam by using the title of caliphate in this process to take care of precautions. Since Islam is the most important element that holds society together, it has been given more prominence by the political power to keep the survive of state and the Muslim subjects together including different ethnicities. That is why goal of Islamic union was very popular during Constitutional Democracy (Gündoğdu, 2016, s.63-75).

Like Ottomanism, Islamism was also not given result of survive and unity of Ottoman State. Nationalism as powerful mean of modernization effected most of ethnical Muslim subjects of Ottoman State. Indeed racist approach was strong before emergence of Islam. Although Islam accepted all Muslims as brothers and sisters during Umayyad Dynasty other ethnical identities had been excluded from political system and caused to be abused (Aydin, p.73-95).

Besides It is obvious that modernization approaches are encouraged and inspired by west. Arabism also a kind of Kemalist nationalism based on the language, culture, language and ethnicity pressing and domaining priority for identity to neglect and forget Islamic background in sense of Turkish Kemalist nationalism Ottoman state not touched Arap language, Balkanian as well as non-muslim languages (Dawisha, 2003, p.16-48). That is why dissolution of Ottoman State was escalated and not succeed to avoid from abolishment in the early twentieth century. Sat1 el husri, one of the Arab intellectual who defended seriously Ottomanism but later converted Arap nationalism after defeat of Ottoman State in the First World War is significant example to figure out how Ottoman multi-naitonal communities during war had tremendous crisis (Cleveland, 2003, p.7-66).

During the First World War, a large part of the Rumelian lands were lost. The political goal of the National Movement was the National Pact. When we look at Erzurum, Sivas, Amasya congresses, we see that the target is political independence and sovereignty within border of the National Pact. For Ergun Özbudun who studied the National Struggle period based on the official documents of the Republic in regard of question of the identity, he states that contrary of Kemalist discourse supporting an ethno-nationalism that places a single identity in a privileged position, legal and cultural aspects of nationalism were more dominant. Indeed, the political discourse should be examined and evaluated in the context of wholeness by caring within the conditions of the period, and separating the main directions from the temporal and secondary deviations. Thus, when Kemalism's discourse of nationalism 
is considered as a cohesion, we can easily claim that its legal and cultural front is more dominant (Özbudun, 1998, p.211).

One of the important parameter of the nationalism is based on the citizenship. Ottoman and Republican nationalist perspectives may be evaluated by application and interpretations of citizenship. The citizenship was based on the ancestry with the regulation of the Ottoman Nationality in 1869. In other words, anyone from Ottoman mother and father were considered as Ottoman citizens. For the foreigners who were born in the Ottoman territories but whose parents were not Ottoman also were supposed to be citizens for restricted cases in exceptional rules (Keyman and İçduygu, 1998, p.172). The first definition of citizenship of Turkish Republic has accepted all people living in Turkey as Turk according to Organization's Fundamental Law Article 88 regardless of religion and ethnicity of people in 1924.

While the citizenship was constructed in the Republican period, modernity and citizenship were established as two basic elements. In fact, the republic has synthesized nation-building with the objectives of culture and citizenship. Contrary to the west based on the philosophy of rights, citizenship was designed within the framework of Plato's virtuous citizenship in which individuals had responsibilities and duties towards the state and the community. Having rights as individuals does not stand out from the first degree. It is not priority to have individual rights comparing western political systems (Keyman and içcuygu, 1998, p.172).

Since the foundation of the Republic, the thesis that Anatolia is a Turkish homeland has been preached. This thesis was taken to the point where it was the first home of Anatolia. The Kemalist founders wanted to legitimize the thesis that Anatolia belonged to the Turks. This idea was first supported in 'Anadolu Mecmuası' in 1917 belonging to 'Türk Ocağı' as a small Turkism or Türkiyecilik against Ottomanism, Islamism and Turanc1lık which aimed greater unity based distinct grounds (Üstel, 1993, p.51). In fact, Turkism was born as a reaction from the idea that other movements were accepted nothing than a dream. Republic founders based their ideas from these experiences when they estimated new plans about modern Anatolia. That is why they did not care other ideologies.

Turkish History Research Association and Turkish Language Association were established to spread a new identity of the Republic ideology through the country. Türk Ocakları (Association) has been revised and reorganized as a Halkevleri (Public Houses) as a part of the Party. Primarily it has been aimed to legitimate the existence of Turkish Republic in the Anatolia during era of Republic by means of dissertation of Turkish history and language. After that Turks has been presented as founder of modern civilizations based on the dissertation that they're the core element of carrying Central Asia culture by emphasizing laicism and pre-Islamic history for construction of new national identity. Thus, they were also secular and equal founder of modern civilizations by excluding Islamic history and culture.

In the Turkish history thesis, it was tried to prove the Turkishness of Anatolia by asserting that the ancient nations of the Sumerians and Hittites, in fact Anatolia, belonged to the Turanian roots. Besides, it was claimed that the ancient Greeks and Hammurabi were Turks. It was based on the thesis that civilization was spread to the world from Central Asia by the peoples of Turkic origin, and thus, those who formed the ancient Anatolian and Mesopotamian cultures were Turks whose Turkishness were not corrupted. In 1924, a new monopolistic educational syllabus imposed a new cultural identity to generations by means of the Tevhid-i Tedrisat Law (Issue 430, 3 March 1924). Especially Turkish History thesis and Turkish Language thesis were introduced in the name of cultural courses in the public schools and universities. 
To sum up it is a fact that late Ottoman reforms in favor of modernization which spread and embraced in all aspects of society and state were not concluded as they planned and desired by state intellectuals and officers. Instead of unifying and keeping the state which had many different ethnical identities, nationalist movements had been instruments of acceleration of state dissolutions in the era of modernization. On the other hand, the same nationalist movements have given a birth of Turkism as a last nationalist movement of the Ottoman state. For Mustafa Kemal and his friends during National Struggle idea and power of Turkish nationalism was very motive for mobilization of civil publics (Keskin, 1999, p.105).

After Nationalist Struggle, Turkish Republic constructed the national state based on this Turkish identity which was very important paradigm and pillar of the modernization of Republic project. Therefore, a new nationalist state has been emerged in the Anatolian land in the $21^{\text {st }}$ century based on the Turkish identity after the long historical background and challenges. Indeed, Kemalist elites has sacrificed materially and spiritually most of things and facilities for the legacy of nationalist state in the process of modernization.

\section{A model of Kemalist nationalism on the shadow of the western footstep.}

For Ayşe Kadıoğlu Turkish nationalism has common features of French nationalism as well as German one. Although it may be mixed model but also depicts handicap due to lack of its original identity. Nationalism of Ziya Gökalp based on the culture and civilization may demonstrate dilemma of this approach. He advocated a model of nationalism based on the individualism, freedom, cosmopolitanism and universal values as well as preserving of unique, original and local values (1972, p.10-48). According to Kadığlu, it is a handicap to preserve local features as well as aiming and keeping universal values. In another word, since modernization is a kind of westernization, it also necessitates to leave local values to arrive universal ones. Otherwise, it may be a barrier, obstacle and dilemma to keep and fallow both dynamics together for modernization (Kadıŏlu, p. 202).

On the other hand, she did not focus on the local characteristics of Kemalist nationalism. In fact, Kemalist nationalism formed a sui generis locality to make forget deep traces of the past from history. Since it excluded Islamic religion and Ottoman history and traditions in the formulation of nationalism it may be said that this model of Kemalist nationalism was closer to the expectations and desires of Kadıoglu based on the universality instead of the locality. Institutions like Halkevleri was just a instrument to carry and propagate western civilizations. That is why British Cultural Committee allowed to engage with Halkevleri (Duman, 2018, p.57-73). Propaganda is very important facility to affect, manipulate and persuade communities in political system (Köseoğlu and Al, 2013, p.103-25). Every kinds of ideologies including capitalism and communism use power of propaganda. It is not used only in modern politics but also in the ancient regimes. Therefore cooperation of Halkevleri and British cultural committee was very important example in sense of propaganda of westernization.

Kemalist nationalism was taken its root of Romantic motives from the ancient civilizations instead of the Ottoman and Islamic heritage. In Kemalist nationalism, the Ottoman and the Islam were consciously neglected and abandoned to be forgotten, to be refuted in the dusty shelves of history. Kemalism is a revolution of values directly targeting the values of the conventional Ottoman rituals (Aydın, 1993, p.226). On the other hand, preIslamic Turkish tribes and victories are highlighted for replacement of the Ottoman and Islamic figures. Thus, the gap between them is attempted to be filled with pre-Islamic period in this sense. 
For Suavi Aydın, three significant characters of republic ideology stand out (1993, p.16). The first of these is a Republican essence, which is the heir of the constitutionalist movement, rejecting the absolute and constitutional monarchy and continues since the I. Constitutional Monarchy. The constitutional monarchy was often the common dream of the intellectuals living in the thirty-year despotism era. The second is the ideology of a nationstate based on a community with a common culture and language that arises from the dissolution of a non-national political formation. Population exchange and loses of Rumeli and Arab provinces are important reasons for the emergence of a nation-state and a homogeneous population. Thirdly, a significant part of the official ideology is a secular identity by rejecting the ideological basis of the Ottoman Empire, which is based on religion. These three features consisted of the chemical elements of modernization.

Ayhan Akman defines the model of Kemalist nationalism as a model of modernist nationalism $(2002, \mathrm{s.81})$. It is very crucial point to distinguish and call the nature and development of Kemalist nationalism as modernist nationalism since countries like Turkey, Russia and Japan do not have colonial background comparing other colonial nationalist movements. According to Akman, Kemalist nationalism is neither civil nationalism nor ethnic nationalism. Ethnic nationalism pays attention to the issue of cultural privilege and originality by means of the definition of nation, emphasizing the unity of race, culture and language. That is why perceiving concept of nationality is based on organic and holistic perspective.

On the other hand, civil nationalism is determined by territoriality, citizenship and civil pride and participation. However ethnic nationalism proposes the main arguments about what constitutes the basic pillars of nationalism. Therefore, while national identity in ethnic nationalism is built on the cohesion, proximity and ethnic purity of the population, it is based on common political ideals and ideas in civil nationalism. The power that holds the nation together in civil nationalism is political ideals like freedom and self-rule. For these political ideals, individuals are effectively and equitably involved in the political process through the parliamentary tool. Thus, every individual has the opportunity and facility to represent himself / herself $(2002$, s.81).

It is a fact that ethnic nationalism is more prevalent in colonial countries. That is why ethnic nationalism is more prevalent in Third World countries of Asian and African continents which have colonial histories. Contrary to colonial countries, civil nationalism is more common in Western Europe and North America in which industrialization has been completed early and nation-state has become more successful.

It cannot be denied that modernist nationalism which also define Kemalist nationalism resemble to ethnic nationalism in some ways. ${ }^{2}$ It is important that individuals are similar in modernist nationalism but the essence that constitutes the nation is not claimed to be a race. Indeed, modernist nationalism is a total westernization project in sense of politics. The basis of national identity constitutes Western cultural rules and moral values (Feyzioğlu, 1986, p.469). The aim here is to become modern like the West. The ultimate expectation is to be Western because it imitates the West from all sides. Thus, Turkish nationalism, which was developed as the official ideology of the Republican period according to Akman, was a total cultural transformation movement which claimed to capture modernity rather than an ethnic originality project (Feyzioğlu, 1986, p.42).

On the one hand, Kemalist nationalism was founded on the rejection of the Ottoman supreme culture and it did not have willing and consent for the possibility of building a

\footnotetext{
${ }^{2}$ For a study focusing details of Turkish nationalism based on the ethno-culturalism during the period of 191938 see ; Ahmet Yıldız, Ne Mutlu Türküm Diyebilene, İstanbul: İletişim Yayınları, 2016.
} 
national culture by using the culture of the periphery. The Kemalist elite, which has the dream of a nation-state instead of the multinationalism in the Ottoman period, of course could not accept Ottoman culture as a supreme common identity. They even conceived this culture and background as a major obstacle to modernization and revolutions (Aydın, 2017, 93-116). For Mustafa Kemal, the imagination and description of a supreme Ottoman State was nothing than a dream comparing contemporary world states (Atatürk, 1960, p.704-19). He points out last Sultan Vahdeddin as traitor due to of escaping and applying as refugee to UK in his long speech for abolishing of Ottoman Kingdom (Atatürk, 1960, p.1239-51).

\section{Conclusion and Evaluation}

It is a fact that modernization in Turkish political history goes back to Ottoman Sate in the beginning of the nineteenth century as a phenomenon before the nationalism of Kemalism has been emerged. While modernization was the aim at the beginning in the sphere of military, it later turned and included on the political, social, economic and legal grounds. It has no doubt that the movement of nationalism, which is a part of modernization in Europe, also affected the Ottoman subjects. In a short period of time, a multinational empire was in the process of dissolution. In the Balkans, Greece, Albania, Bulgaria and others left state and gained independence.

On the other hand, the Arabs, in the First World War, fallowed a cooperation with British caused founders of Republic elites to consolidate the nation-state dreams and enthusiasm. Previous Islamist intellectuals like Sat1 el husri, one of the Arab intellectual who defended seriously Ottomanism but later converted Arap nationalism after defeat of Ottoman State in the First World War is obvious example to observe how Ottoman multi-national societies during war had tremendous crisis. Therefore, Kemalist nationalism left Turanism, Islamism and Ottomanism aside the politics of style and began to implement a project of modern, western homogeneous nation-building.

Although Kemalist nationalism accepted the West as a reference in every field, it was not very successful from the point of political rights and democracy. Democracy and political institutions remained in a way that was far from the western orbit. In the context of democratic institutions, unfortunately the West did not receive enough examples. Under the pretext of not being more suitable to the conditions of time, the nation could not benefit from the blessing of democracy in the Western sense. The multi-party system and the functioning of democracy have been suspended due to the fear that modernization can be prevented.

In the society engineering style, elitist politicians acted in the form of a tutelage in the name of people who know the demands of the people better than themselves. In spite of the public, for sake of the people, the reforms took place on a non-democratic basis, that is, away from the institutional structure of the West. Although, in the twentieth century, after the First World War, there were problems in the West in terms of democracy, the Single Party period was a great paradox for the Kemalists who regarded and fallowed the West as a single truth from the point of history of democracy and humanism.

To sum up, Kemalist nationalism as a modernist nationalism is a project that adopts and imitates all aspects of material and spiritual western civilization. In order to achieve this goal, it was decided to break ties with the past. A number of reforms were carried out for this purpose. That is why the caliphate was abolished, the Latin alphabet was adopted, the civilized clothing style was adopted, the women allowed to participate in the public sphere through professionalization, the principle of secularism was accepted, madrasahs, dervish lodges (tekke) and orders (zaviyeth) were closed, the hat revolution was made, the Swiss civil code and the Italian penal code were quoted. With these reforms, Westernization was tried to be captured and imposed in social, political and cultural life. 


\section{KAYNAKÇA}

Akçura, Y. (1976). Üç Tarz-1 Siyaset, Türk Tarih Kurumu Yayınları, VII Dizi, S. 73.

Akman, A. (2002). "Milliyetçilik Kuramında Etnik/Sivil Milliyetçilik Karşıtlığı", Modern Türkiye'de Siyasi Düşünce: Milliyetçilik, c.4, İstanbul: İletişim Yayınları.

Anderson, B. (1991). Imagined communities: Reflections on the origin and spread of nationalism. New York: Verso Books, 1991.

Atatürk, M. K. (1959). Nutuk : vesikalar. (C.III). Ankara : Türk Devrim Tarihi Enstitüsü.

Atatürk, M. K. (1960). Nutuk : 1920-1927. (C.II). Ankara : Türk Devrim Tarihi Enstitüsü.

Aydın, E. (2017). Bediüzzaman Said Nursi'nin eserlerinde din-siyaset ilișkisine dair bir inceleme. Yayınlanmamıș doktora tezi, İstanbul: Marmara Üniversitesi SBE.

Aydın, E. (2018). “İslam'da demokratik bir hilafet tasavvuru mümkünmü?”, Muhafazakar Düşünce Dergisi, (54), p.73-95.

Aydın, S. (1993). “Modernleşme ve Milliyetçilik”, Ankara: Gündoğan.

Cleveland, W. (1971). The making of an Arab nationalist Ottomanism and Arabism in the life and thought of Sati al-Husri. (C. XV, 211 s.). Princeton : Princeton University.

Çağaptay, S. (1999). “Türkiye'de İslam, Laiklik ve Milliyetçilik: Türk Kimdir?”, İstanbul: İstanbul Bilgi Üniversitesi Yayınları.

Dawisha, A. (2003). Arab nationalism in the Twentieth-Century : from triumph to despair. (C. VI, 340 s.). Princeton : Princeton University.

Duman, M . (2018). II. Dünya Savaşı Sonrasında Dış Politikada Doğrultusunda Gelişen Kültürel Bir İttifak: Halkevleri ve İngiliz Kültür Heyeti. Bitlis Eren Üniversitesi İktisadi Ve İdari Bilimler Fakültesi Akademik İzdüşüm Dergisi, 3 (3), 57-73.

Eisenstadt, S.H. (1966). Modernization, Protest and Change, N.J.: Prentice-Hall Inc.

Göçek, F.M. , (2002). “Osmanlı Devleti'nde Türk Milliyetçiliğinin Oluşumu: Sosyolojik Bir Yaklaşım”, Modern Türkiye'de Siyasi Düşünce: Milliyetçilik, c.4 İstanbul: İletişim Yayınları.

Gökalp, Z. (1972). Hars ve Medeniyet, haz. Yalçın Toker, 2. Bs., Ankara: Diyarbakır'1 Tanıtma ve Turizm Derneği..

Gündoğdu, M . (2016). Namık Kemal'in Selimiyye Adlı Naziresinde İttihâd-1 İslam Hedefi. RumeliDE Dil ve Edebiyat Araştırmaları Dergisi, (7), 63-75.

Hobsbawm, E. J. (1995). Nations and nationalism since 1780 (C. VIII, 206 s.). Cambridge : Cambridge University, pp.14-45.

Kadığlu, A. (1998). "Milletini Arayan Devlet: Türk Milliyetçiliğinin Açmazları", 75 Yılda Tebaadan Yurttaşa Doğru, (der. Artun Ünsal), İstanbul: Tarih Vakfı.

Karpat, K. (2012). Balkanlarda Osmanlı Mirası, Timaş, çev. Recep Boztemur, 2. bs., İstanbul : Timaş Yayınları.

Kemal, N.K. (2011). Vatan Yahut Silistre. İstanbul, Kum Saati Yayınları.

Keskin, M. (1999). Atatürk'ün Millet ve Milliyetçilik Anlayışı, Ankara: Atatürk Araştırma Merkezi.

Keyman F. ve İçduygu, A. (1998). "Türk Modernleşmesi ve Ulusal Kimlik Sorunu” 75 Yılda Tebaadan Yurttaşa Doğru, İstanbul: Tarih Vakfi. 
Kongar, E. (1981). Toplumsal Değişme Kuramları ve Türkiye Gerçeği, İstanbul: Remzi Yayınları.

Köseoğlu Y. ve Al H. (2013), Bir Siyasal Propaganda Aracı Olarak Sosyal Medya, Akademik İncelemeler Dergisi, Cilt:8, Sayı:3, s.103-25.

Kushner, D. (1977). “The Rise of Turkish Nationalism 1876-1908” London: Frank Cass.

Özbudun, E. (1998). "Millî Mücadele ve Cumhuriyet'in Resmi Belgelerinde Yurttaşlık ve Kimlik Sorunu", 75 Yılda Tebaadan Yurttaşa Doğru, (der. Artun Ünsal), İstanbul: Tarih Vakfi.

Özkırımlı, U. (2009). "Milliyetçilik Kuramları: Eleştirel Bir Bakış”, Ankara: Doğu-Batı. Tevhid-i Tedrisat Law (Issue 430, 3 March 1924). http://www.mevzuat.gov.tr/MevzuatMetin/1.3.430.pdf, (01-02-2019).

Üstel, F. (Ocak 1993). “Türk Milliyetçiliğinde Anadolu Metaforu”, Tarih ve Toplum, no.109, p.51.

Yıldız, A. (2016). Ne Mutlu Türküm Diyebilene, İstanbul: İletişim Yayınları. 